\title{
Climatology of Severe Hail in Finland: 1930-2006
}

\author{
JARi-Petteri Tuovinen, ARi-Juhani PunkKa, Jenni RAuhala, And HARri Hohti \\ Finnish Meteorological Institute, Helsinki, Finland \\ DAVID M. SCHULTZ \\ Division of Atmospheric Sciences and Geophysics, Department of Physics, University of Helsinki, and Finnish \\ Meteorological Institute, Helsinki, Finland
}

(Manuscript received 1 July 2008, in final form 10 October 2008)

\begin{abstract}
A climatology of severe hail ( $2 \mathrm{~cm}$ in diameter or larger) in Finland was constructed by collecting newspaper, storm-spotter, and eyewitness reports. The climatology covered the warm season (1 May-14 September) during the 77-yr period of 1930-2006. Altogether, 240 severe-hail cases were found. The maximum reported severe-hail size was mainly $4 \mathrm{~cm}$ in diameter or less (65\% of the cases), with the number of cases decreasing as hail size increased. In a few extreme cases, 7-8-cm (baseball sized) hailstones have been reported in Finland. Most of the severe-hail cases (84\%) occurred from late June through early August, with July being the peak month (almost $66 \%$ of the cases). Most severe hail fell during the afternoon and early evening hours 1400-2000 local time (LT). Larger hailstones (4 cm or larger) tended to occur a little later (1600-2000 LT) than smaller $(2-3.9 \mathrm{~cm})$ hailstones (1400-1800 LT). Most severe-hail cases occurred in southern and western Finland, generally decreasing to the north, with the majority of the cases near population centers. The proportion of severe hail less than $4 \mathrm{~cm}$ in diameter is greatest over the agricultural area in southwestern Finland where crop damage caused by severe hail is more likely to be reported. The underreporting of hail is a particular problem across much of Finland because of the vast forest and lake areas, low population density, and relatively small hail swaths. Since the 1990s, a greater interest in severe weather among the general public and media, a storm-spotter network, improved communications technology, and an official Web site for reporting hail have increased the number of reported hail cases. According to the most recent $10 \mathrm{yr}$ (1997-2006), Finland experiences an annual average of 10 severe-hail cases during 5 severe-hail days.
\end{abstract}

\section{Introduction}

Over the past $50 \mathrm{yr}$, less research on convective storms has occurred in Europe compared to the United States. This lack of research is probably because of the small number of interested scientists and the general misassumption that severe convective weather rarely occurs. Particularly in northern Europe (including Finland), the much longer cool season relative to the warm season and the abundance of cool-season hazardous weather (e.g., heavy snowfall, deep low pressure centers with gale-force winds) fuels the perception that severe convective weather is not as important.

Surprisingly, the Finnish Emergency Response Centers receive more weather-related phone calls from the

Corresponding author address: Jari Tuovinen, Finnish Meteorological Institute, P.O. Box 503, FIN-00101 Helsinki, Finland. E-mail: jari.tuovinen@fmi.fi general public during the warm season than during the cool season. Most calls report the impact of hazardous weather on societal infrastructure (e.g., fallen trees, floods blocking roads, etc.). Specifically, the average number of calls during the five-month May-September period over the $7 \mathrm{yr}(2001-07)$ was 2342 (2.2 calls day $^{-1}$ ), compared to 1425 for the 4-month November-February period $\left(1.8\right.$ calls day $\left.{ }^{-1}\right) .{ }^{1}$ Thus, severe convective weather in Finland has a potentially large and unappreciated societal impact.

In Finland, severe convective storm research has started only in recent years. Punkka and Bister (2005) studied mesoscale convective system occurrence in and

\footnotetext{
${ }^{1}$ To obtain these values, we have eliminated November 2001, the month with the record number of phone calls (over 7000), mostly from two strong winter storms. November 2001 easily bested the month with the second highest number of reports, August 2005 (over 1500 calls), justifying its exclusion from these statistics.
} 
TABLE 1. Information of peak month(s) of hail cases from different studies across the world.

\begin{tabular}{|c|c|c|c|}
\hline Study & Study area & No. of study years & Peak month(s) of hail cases \\
\hline Dessens (1986) & Southwest France & $1952-80$ & Jun-Jul \\
\hline Federer et al. (1986) & Central Switzerland & $1977-81$ & Jun-Jul \\
\hline Kotinis-Zambakas (1989) & Greece & $1931-75$ & Jun \\
\hline Sánchez et al. (1996) & North Spain (Leon) & 1986-92 & May-Jul \\
\hline Simeonov (1996) & Bulgaria & $1957-72$ & May-Jun \\
\hline Vinet (2001) & France & 1987-96 & $\begin{array}{l}\text { Summer hail season } \\
\text { May-Sep }\end{array}$ \\
\hline Webb et al. (2001) & United Kingdom & 1980-99 & Jun-Jul \\
\hline Giaiotti et al. (2003) & $\begin{array}{l}\text { Parts of Italy, Bulgaria, } \\
\text { Greece, Spain, } \\
\text { France, and the } \\
\text { United Kingdom }\end{array}$ & $1988-2001$ & May-Jul (northeast Italy) \\
\hline Paul (1980) & $\begin{array}{l}\text { South-central Canada } \\
\text { (Saskatchewan) }\end{array}$ & $1973-77$ & May-Jun \\
\hline Etkin and Brun (1999) & Canada & $1977-93$ & Jun-Aug \\
\hline Lemons (1942) & United States & $1899-1938$ & May-Jun \\
\hline Kelly et al. (1985) & United States & $1955-83$ & Apr-Jul \\
\hline NSSL hazards map & United States & 1980-99 & $\begin{array}{l}\text { Apr-Jun in the south } \\
\text { and central parts, } \\
\text { Jun-Jul in the } \\
\text { northern parts }\end{array}$ \\
\hline Changnon and Changnon (2000) & United States & 1896-1995 & Apr-Jul \\
\hline Schaefer et al. (2004) & United States & 1955-2002 & Apr-Jul \\
\hline Doswell III et al. (2005) & United States & $1955-99$ & $\begin{array}{l}\text { Apr-Jun in the south } \\
\text { and central parts, } \\
\text { Jun-Jul in the } \\
\text { northern parts }\end{array}$ \\
\hline Schuster et al. (2005) & Southeast Australia & $1935-2003$ & Nov-Dec \\
\hline Zhang et al. (2008) & China & $1961-2005$ & $\begin{array}{l}\text { Feb-Apr in the south, } \\
\text { May-Aug in the central } \\
\text { and northern parts }\end{array}$ \\
\hline Frisby and Sansom (1967) & Tropics & Unknown & $\begin{array}{l}\text { Mainly during spring } \\
\text { and fall }\end{array}$ \\
\hline Present study & Finland & 1930-2006 & Jun-Aug \\
\hline
\end{tabular}

around Finland during 2000-01. A Finnish derecho (e.g., Johns and Hirt 1987) was studied by Teittinen and Punkka (2004) and Punkka et al. (2006). A microburst at the heavily instrumented Hyytiälä forestry field station in southern Finland was documented by Järvi et al. (2007). A climatology of tornadoes in Finland has been constructed by Teittinen and Brooks (2006), and Doppler and dual-polarimetric radar reports of tornadic supercells were analyzed by Teittinen et al. (2006) and Outinen and Teittinen (2007). No previous climatologies of hail in Finland have been made, nor have hail reports been systematically collected previously by the Finnish Meteorological Institute (FMI). In fact, as far as we know, no hail climatologies have been published for locations as far north as Finland $\left(60^{\circ}-70^{\circ} \mathrm{N}\right)$. Thus, the present study provides a unique opportunity to examine the occurrence of severe weather, specifically hail, at a northern high-latitude location.

Reports of severe weather in a country, that country's perception of its severe convective storm potential, and its forecast and warning process are intimately linked (e.g., Doswell 2001, p. 14 and 18; Doswell 2003). Climatologies can be useful to educate people about the potential risk of severe weather, and the collection of severe weather reports are useful for recognizing the severe-weather threat and verification of weather warnings. Even for the 26 European countries that issue warnings for severe thunderstorms, only $15(58 \%)$ use hail as a warning criterion, with 8 of those 15 countries issuing warnings for any sized hail, and 4 issuing warnings for hail $2-2.5 \mathrm{~cm}$ in diameter or larger (Rauhala and Schultz 2008).

Previous climatological studies of hail in Europe and elsewhere in the world are summarized in Table 1. Although we are not aware of any climatologies of hail in eastern Europe, hail suppression programs were quite active at one time (e.g., Battan 1977) and still continue in some locations. In addition, some other studies of hailstorms have been presented in Europe by Morgan (1973), Waldvogel et al. (1979), Ludlam (1980), Schmid 
and Waldvogel (1986), Houze et al. (1993), Ramis et al. (1997), Fraile et al. (2001, 2003), and López et al. (2001).

Several points are worth making about these studies. First, the number of hail studies is likely larger than those in Table 1, but most probably have been written in each country's native language with no English translation. Second, many climatological studies in Europe are related to hail-pad reports that record all hail sizes, not just the larger severe-hail cases $(2 \mathrm{~cm}$ in diameter or larger). Third, most climatologies (e.g., Dessens 1986; Sánchez 1996; Giaiotti et al. 2003; Schuster et al. 2005) examine only a small part of each country because of the vulnerability of agriculture or the location of a hailpad network, for example. Consequently, the number of nationwide hail climatologies is relatively few.

In northern Europe, statistics of hail reports do not exist, and only isolated cases have been documented. We contacted the Swedish, Norwegian, Danish, and Estonian National Hydrometeorological Services to ask about hail cases in their respective countries-none of them had systematically been collecting large-hail reports. The Swedish Meteorological and Hydrological Institute and Estonian Meteorological and Hydrological Institute said that hail occurs primarily during the warm season (late May to September in Sweden and May to September in Estonia) with hail $2 \mathrm{~cm}$ in diameter or larger being quite rare. The largest reported hailstones have been 7-8 $\mathrm{cm}$ in Sweden and 8-9 $\mathrm{cm}$ in Estonia with some local damage caused. The Norwegian Meteorological Institute and Danish Meteorological Institute both replied that hail is an infrequent event in their countries. Hail diameter surpassing $1-2 \mathrm{~cm}$ is rarely seen in southeastern Norway (Østlandet and Sørlandet regions) where the strongest thunderstorms occur. The largest documented hail case in Norway was $4 \mathrm{~cm}$ in diameter and occurred near Oslo on 7 June 2004. The climatology of hail in Sweden and Estonia differs from Norway and Denmark, most likely because of Norway and Denmark's nearby location to the cool Atlantic Ocean, as well as Norway's mountainous terrain, inhibit convective storm development suitable for hail formation relative to that of Sweden and Estonia.

As in other parts of the world, most hail cases in Finland are isolated, short-duration, and small-scale phenomena. Hail cases in Finland are often undetected because of the limited extent of the hail swaths, vast forest and lake areas (Finland is Europe's most forested country with $74.2 \%$ forested and $10 \%$ lakes), and low population density (an average of 16 people $\mathrm{km}^{-2}$, equivalent to the population density of Colorado, with Lapland in northern Finland having as few as 2 people $\mathrm{km}^{-2}$, equivalent to the population density of Wyoming). Furthermore, because convective storms in Finland are generally smaller than in the central United States, hail swaths in Finland are also small, further making collecting hail reports difficult. Small hail can occur during the warm season with nonsevere thunderstorms all across Finland, but often the size of the hailstones is no bigger than a pea (roughly $0.5-1 \mathrm{~cm}$ in diameter). Hail of this size generally does not cause much damage, but long-lasting cases may locally flatten crops. In such cases, farmers are motivated to report hail damage to their insurance company or to the Ministry of Agriculture because crop fields are usually insured against severe weather. Although hailstorms producing widespread damage are rare in Finland, hail as large as tennis balls or baseballs $(6.4-7.0 \mathrm{~cm}$ or $2.5-2.75 \mathrm{in}$.) or larger can cause local property damage, broken windows, injuries, and damage to crops (Tuovinen 2007). For example, severe hailstorms caused over a million euros of damage in eastern Finland on 10 July 2006, as 7-cm hailstones and severe wind gusts damaged about 1000 cars and numerous buildings along a hail swath that was nearly $200 \mathrm{~km}$ long (Tuovinen 2007).

Despite the challenges in collecting hail reports to build a hail climatology, Finland does have some advantages compared to other countries. First, because of the commercial success of Nokia mobile phones, communications technology in Finland is pervasive. In 2006, $97 \%$ of Finnish households had a mobile phone and $65 \%$ had Internet access (see more information online at http://www.stat.fi/til/jvie/2006/index_en.html). Such technology allows more rapid and efficient reporting between the public, emergency authorities, and FMI. Second, since 2004, FMI has organized about 50 storm spotters into a network to observe and report severe weather, particularly hail of all sizes. Third, because of the relatively rarity of hail and the importance of agriculture to the Finnish economy before the 1960s, hail is a newsworthy occurrence.

There are three main goals to this article. The first is to collect reports of severe hail $(2 \mathrm{~cm}$ in diameter or larger) in Finland. The second is to describe a process for collecting these reports in order to show others how such reports could be collected for their own country or region. The third is to use the data collected to create a climatology of severe hail in Finland. The structure of the present article is as follows. In section 2, the methods to collect severe-hail cases are described. The yearly, monthly, diurnal, and geographical distributions of severe hail are presented in section 3. Finally, section 4 concludes this article.

\section{Dataset sources and methods}

Building a dataset of severe weather in a sparsely populated country that had no formal mechanism for 
reporting severe weather for many years is challenging and time consuming. Creating a climatology requires multiple approaches to get enough data for satisfactory results. Furthermore, creating and maintaining a durable hail-reporting system is essential to growing the dataset in the future. This was the starting point for gathering data for this study.

For this study, we limit ourselves to severe hail, those cases where the maximum hailstone size reported was $2 \mathrm{~cm}$ in diameter or larger, mimicking the $1.9-\mathrm{cm}(3 / 4 \mathrm{in}$.) criterion for severe hail in the United States (e.g., Johns and Doswell 1992). The 3/4-in. criterion in the United States came from "the smallest size of hailstones that could cause significant damage to an airplane flying at speeds between 200 and $300 \mathrm{mph}$ [89 and $134 \mathrm{~m} \mathrm{~s}^{-1}$ ]" (Galway 1989, p. 588). Large hail is defined as severe hail less than $4 \mathrm{~cm}$ in diameter $(2-3.9 \mathrm{~cm})$. Very-large hail in this study is defined as severe hail equal to or exceeding $4 \mathrm{~cm}$ (1.6 in) in diameter, somewhat similar to the definition of significant severe hail in the United States: 2 in. $(5.1 \mathrm{~cm})$ in diameter (Hales 1988). A severehail day is defined as a day with at least one severe-hail report in Finland.

Sometimes multiple hail reports may occur in close proximity in space or time, but be part of the same storm. Unless stated explicitly to the contrary, the word report is used in this article to describe each reported observation of hail and the word case to describe each hail event. To be considered a unique severe-hail case for this dataset, the difference between hail reports must be $15 \mathrm{~min}$ or larger and $20 \mathrm{~km}$ or further, mimicking the requirements in the United States of $15 \mathrm{~min}$ and $16 \mathrm{~km}$ (Schaefer et al. 2004). This definition may result in a hail swath by a single strong thunderstorm being recorded as several hail cases in our dataset. The likelihood of this possibility may be significant during outbreak days with long-track storm systems like 10 July 2006. To examine the likelihood of overestimating the number of hail events, radar data for all hail cases from 2004 to 2006 was examined for evidence of multiple reports from a single storm exceeding the 15 -min and $20-\mathrm{km}$ thresholds. Results from this analysis suggest that approximately $15 \%-20 \%$ of cases may be attributed to storms that produce multiple severe-hail cases, by our definition.

\section{a. Severe-hail data sources}

Six different approaches were used to obtain possible hail reports. First, convective storms that were particularly intense, produced hailstones that were unusually large, or caused damage to agricultural crops or property often were reported in the news. To find these events, newspapers between 1930 and 1993 were studied by browsing microfilmed archives of major national news- papers (e.g., Helsingin Sanomat, Savon Sanomat, Aamulehti, and Turun Sanomat) in the National Library of Finland. Other local newspapers with smaller circulations were examined if more details on a particular case were needed. The study period was from 1 May to 14 September each year. There were two main reasons for this limitation: large-hail cases tend not to occur outside this period, as will be shown later in this article, and the huge task of browsing hundreds of microfilms is reduced by eliminating the cool season. The likelihood of missing a severe-hail event from the microfilms by not seeing it was possible, but likely small. The number of newspaper pages that were examined was near 140000 . Typically, newspaper articles on severe hail included information on damage, estimated hail diameter, location, and time of occurrence. Some articles had a photograph of severe hail or its damage. Newspaper articles of severe-weather events between 1994 and 2005 were found by using the Internet databases for Helsingin Sanomat, Iltalehti, IltaSanomat, Aamulehti, Savon Sanomat, and Kaleva newspapers. In these cases, searching for severe hail articles was easier because keyword searches like large hail, severe hail, hailstorm, hail, hail fall, and strong thunderstorms were possible. Although newspapers were not examined for 2006, storm spotters had confirmed nearly all newspaper reports of hail since 2004, thus we expect not to lose many possible hail cases from 2006 in this manner. Altogether, 155 (65\%) of the 240 cases in this study are from newspaper articles.

Second, a request for historical and recent severe-hail reports was placed on the front page of the FMI Web site (see online at http://www.fmi.fi) during May, June, and July 2006. The Web proved to be an efficient way to collect hail reports because most of the e-mailed replies included a photo of either damage or hail. Every potential report received in this manner was verified by examining weather radar data to see if high radar reflectivity factor occurred at the reported location and time. Some problems occurred with a few eyewitness reports because of a mistaken time, date, or even year of report. In these cases, a request to clarify the information was sent back to the observer. If clarification was not received, the report was rejected. Only two reports did not match with the radar data and further clarification was not received from the observer. This process resulted in $46(19 \%)$ of the 240 cases in the study.

Third, some recent hail reports were collected through a small network of storm spotters in Finland. Since 2004, about 50 storm spotters have been cooperating with FMI on a hail-observation program to develop an operationally tested, hail-probability algorithm. Storm spotters contributed 35 severe-hail reports $(15 \%$ of the 240 cases) to the dataset. 
Fourth, three major insurance companies (If, A-Vakuutus, and Pohjola) and the Federation of Finnish Insurance Companies were approached for records of hail damage to vehicles or other property. Unfortunately, such information was not available because hail damage to vehicles in Finland is classified in the same category as collision accidents (Tuovinen 2007).

Fifth, the synoptic weather observations (manual weather observations 2-8 times day ${ }^{-1}$ at 0300, 0600, 0900, $1200,1500,1800,2100$, and 0000 UTC) from 1950 to 2005 were also checked for any hail cases. If the surface air temperature was less than $10^{\circ} \mathrm{C}$, the potential hail event was eliminated from consideration to eliminate graupel reports that may have been recorded as hail. Similar issues with hail datasets have been noted in the western United States and Canada (e.g., Lemons 1942; Etkin and Brun 1999). Close to 100 reports were found from the database, but the lack of information about their size led to rejection of all but one case. This case was retained because the meteorological observer who recorded the report was able to recall additional details about the case.

Sixth, three cases were found through the annual yearbooks of Finland (Mitä-Missä-Milloin, published by Otava). Finally, the different sources of data were combined and the reports were evaluated using the methods described in this section. Some of the hail cases were confirmed by multiple sources, especially for the last $10 \mathrm{yr}$. The resulting dataset is 240 severe-hail cases on 161 severe-hail days in Finland during the 77 warm seasons from 1930 to 2006.

\section{b. Case classification}

To address the credibility of this dataset, we developed a classification scheme: confirmed, probable, and possible. A report was classified as confirmed if a picture of a hailstone clearly shows the diameter $2 \mathrm{~cm}$ or larger. The strict requirement of a photo resulted in $38(16 \%)$ cases in the confirmed category. The number of cases with a photo has increased significantly in recent decades. In fact, 30 ( $79 \%$ of the 38 confirmed cases) cases with photos have occurred since 1985. Many newspaper reports were classified as probable for a credible damage or eyewitness report of severe hail. This credibility category was largest with $166(69 \%)$ of cases. Possible cases were those that were about $2 \mathrm{~cm}$ in diameter, so they may not be precisely classified as severe hail, with $36(15 \%)$ cases. Cases from all probability classes were included in this study.

\section{Severe-hail distributions in Finland}

\section{a. Annual distribution}

The distributions of severe-hail cases and severe-hail days 1930-2006 include a notable variation from year to

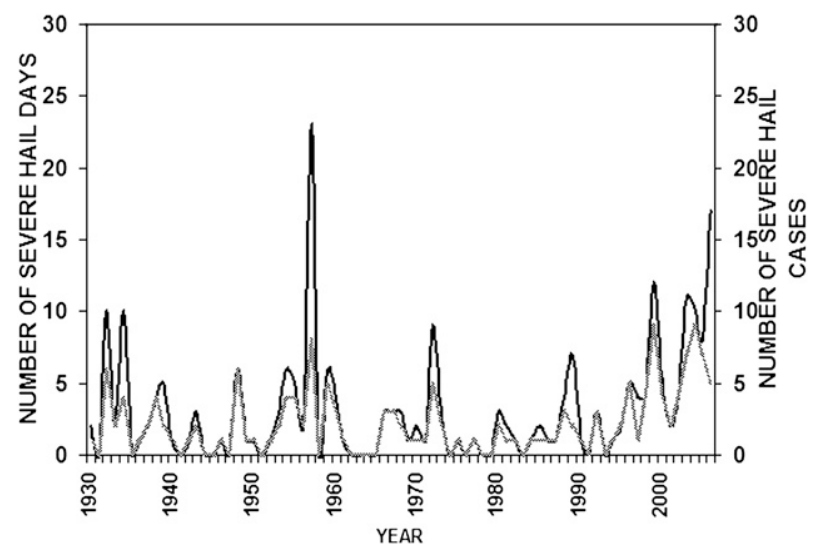

FIG. 1. Number of severe-hail days per year (gray line) and number of severe-hail cases per year (black line) during 1 May14 Sep 1930-2006.

year (Fig. 1). The year with the largest number of cases ( 23 cases during 8 severe-hail days) was 1957, although the number of cases was probably larger as news reports of strong thunderstorms and hail damage were reported frequently in July 1957. The synoptic pattern in July 1957 was favorable for hailstorms nearly every day as a low pressure center was situated over southern Norway for much of the month, maintaining warm, moist midlatitude air over much of Finland for weeks.

Since the late 1990s, the number of severe-hail cases and severe-hail days has been increasing (Fig. 1). Four out of the 10 most active summers for severe hail have occurred during the last $7 \mathrm{yr}$ (1999-2006). This increase in the number of cases is mostly due to the more efficient collection of reports by FMI, more widespread interest in severe weather among the general public and media, more systematic reporting of hail by the storm spotters, and advanced technology (e.g., mobile phones, digital cameras, easy data transfer via e-mail, Internet, etc.). A similar trend of increasing hail reports is also occurring in the United States (Schaefer et al. 2004) and southeastern Australia (Schuster et al. 2005). Thus, the Finnish dataset appears to be more consistent from year to year during the last 10 years. Similarly, an increase in confirmed tornado reports in Finland over the last decade has also been noticed (Teittinen and Brooks 2006).

During this $10-\mathrm{yr}$ period, the annual average number of severe-hail cases is 10 , occurring during an average of 5 severe-hail days (Fig. 1). The number of severe-hail cases and severe-hail days are nearly equal over the whole $77 \mathrm{yr}$ of the dataset (ratio between observed days and events is 0.67 ), implying that in many cases only one severe-hail case is reported each day, as is the case for earlier years in the dataset. Altogether 120 of the 161 days (nearly $75 \%$ ) had only one case, although in more 


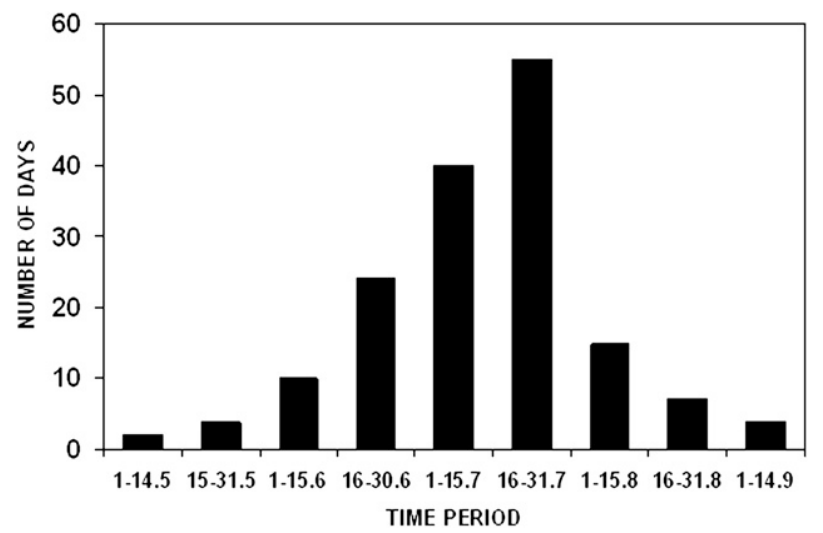

FIG. 2. Distribution of severe-hail days in 2-week periods from 1 May to 14 Sep 1930-2006. Date and time format follows European format (e.g., 1-14.5 is 1-14 May).

recent years, two or more cases per day have been more common.

What causes the variability in hail cases and hail days before the 1990s may be partially due to cooler summers when less convection occurs (1962-65 and few summers of late 1970s). However, untangling the relationship between summer temperature and hail reports is complicated because of the inadequacies in reporting.

Comparing these results to those from other European countries and elsewhere in the world is somewhat challenging. There are only a few published statistics on the number of severe-hail cases from other European countries (e.g., Webb et al. 2001). Furthermore, most of the annual distributions include cases with all hail sizes or only-hail days; a "severe-hail day" is not a concept that is widely used in Europe. Hail days could have two meanings: at a point or summed across the country. Changnon $(1999,2000)$ studied hail days in the United States with a dataset of $100 \mathrm{yr}$ (1896-1995) and found that the highest hail-day frequency occurs along the eastern ranges of the Rocky Mountains, but most of the United States experience only three or fewer hail days a year. Nevertheless, the maximum number of hail days (all hail sizes) in the southern Great Plains of the United States is more than 100. Kelly et al.'s (1985) database of over 29000 storms causing hail larger than $19 \mathrm{~mm}$ (1955-83), Schaefer et al.'s (2004) database of the 155005 large hail reports, and Basara et al.'s (2007) severe-hail swath analysis also suggests this argument. Paul (1980) showed that during a 2-yr test period (1974-75) in southern Saskatchewan, central Canada (near $\left.50^{\circ} \mathrm{N}\right), 17$ (1974) and 20 (1975) large-hail days occurred. As Etkin and Brun (1999) noted, there is a clear difference between a study based on automatic hail station reports and more detailed small-scale study concluded by Paul (1980). On average, there are 1-3 hail days in Canada

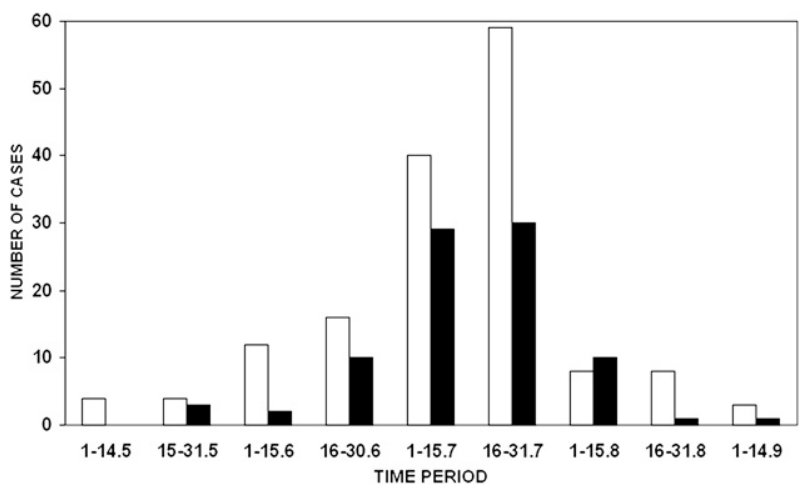

FIG. 3. Distribution of severe-hail cases from 1 May to 14 September divided into 2-week periods. White bars indicate number of cases of large hail (2-3.9 cm in diameter), and black bars indicate number of cases of very-large hail ( $4 \mathrm{~cm}$ or larger). Date and time format follows European format (e.g., 1-14.5 is 1-14 May).

with a maximum of over 5 hail days in parts of central British Columbia and Alberta (Etkin and Brun 1999). Both the southern and central United Kingdom had an average of 3-6 large-hail days $\left(1000 \mathrm{~km}^{2}\right)^{-1}$ (100 yr $)^{-1}$ during 1950-99 (Webb et al. 2001). Southwestern France and the Friuli-Venezia Giulia area of northeastern Italy experienced an average of 39 and 55 hail days (any hail size), respectively, during 1988-2001 observed by hail pads (Fig. 9 in Giaiotti et al. 2003).

\section{b. Monthly distribution}

Most of the severe-hail days in Finland occur during July, particularly during the last two weeks of July when over $30 \%$ of severe-hail days occur (Fig. 2). In Canada, June and July are the peak months for hail, and major hailstorms have occurred mostly in July (Etkin and Brun 1999). In China (Zhang et al. 2008), the majority of severe-hail days occur between May and September, although southern China experiences hail earlier in spring. Comparable distributions for other countries are not available.

The monthly and diurnal distributions of severe hail are divided into two size categories: less than $4 \mathrm{~cm}(1.6$ in., large hail) and $4 \mathrm{~cm}$ or larger (very large hail). The vast majority of severe hail ( $94 \%$ of all cases) in Finland occurred during June, July, and August (Fig. 3), with July being the most active month with $66 \%$ of the cases. The peak time for severe hail was late June to early August, when over $85 \%$ of cases occurred. Although very large hail peaked in late July, the peak for large hail was throughout July (Fig. 3).

These results are generally consistent with the thunderstorm season in Finland, a sensible result considering that both phenomena are largely dependent on deep moist convection. Specifically, cloud-to-ground lightning 


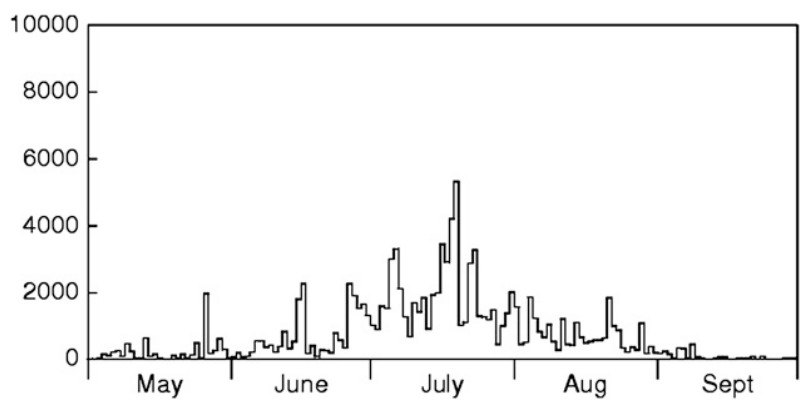

FIG. 4. The daily mean number of cloud-to-ground flashes in Finland: 1998-2007 (Tuomi and Mäkelä 2003).

occurrence during 1998-2007 (Tuomi and Mäkelä 2003) indicates that the thunderstorm season starts in May, peaks in mid-July, and decreases until the end of August (Fig. 4).

Splitting the data into large and very large hail may cause some problems in interpretation because of the small sample sizes (e.g., Doswell 2007). For example, in early August, very large hail seems to be more common than large hail (Fig. 3). Also, the total number of cases in early August is low compared to July cases (Fig. 3). In fact, the suspected reports of hail from radar data during 2003-06 show that July and August should have comparable numbers of hail cases (Saltikoff et al. 2008). The reasons, other than a small sample size, are unknown, but might be related to undiscovered characteristics of the seasonal synoptic pattern in Finland that favors convective storms.

Few articles have presented the seasonal behavior of severe hail. In the United States, severe hail reports are most common during April and May, especially over the central Plains and the eastern United States (Schaefer et al. 2004). Online hazards maps by Harold Brooks at the National Severe Storms Laboratory (available online at http://www.nssl.noaa.gov/hazard; Doswell et al. 2007), as well as those in Lemons (1942), show the seasonal cycle of severe hail for the United States. As the year progresses from March through June, the probability of severe hail shifts northward. The northward movement has also been noted in China where the hail season occurs in southern China during spring (February-April) and in central and northern China during May-September (Zhang et al. 2008). In central Canada (Paul 1980), 28\% of all severe-hail cases occurred during the peak month of July. In the United Kingdom, June and July are the peak months for severe hail, although hail can occur year-round (Webb et al. 2001). The same kind of behavior is found from southwestern France for any hail size (Dessens 1986; Fraile et al. 2003). Hail (all hail sizes) is most common in June

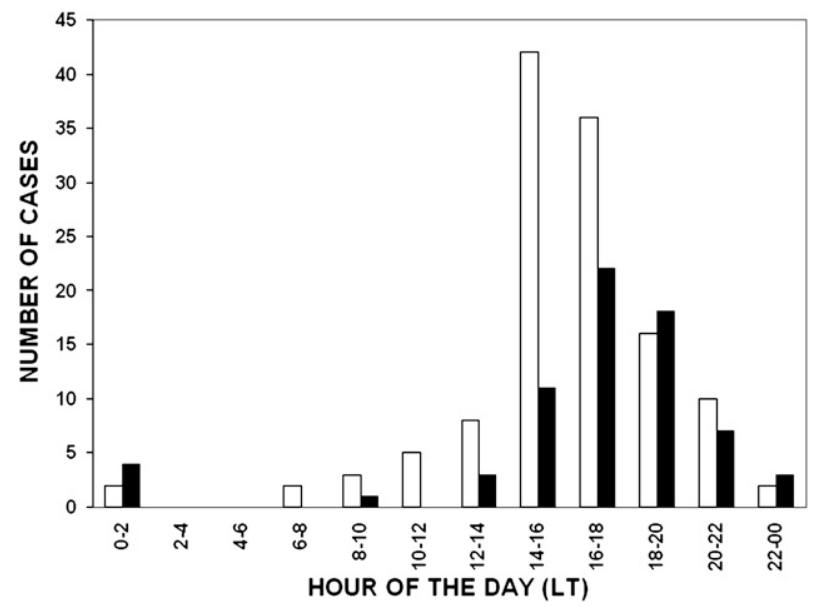

FIG. 5. Diurnal distribution of severe hail in 2-h periods (LT). White bars indicate the number of cases of large hail $(2-3.9 \mathrm{~cm}$ in diameter) and black bars indicate the number of cases of verylarge hail (4 $\mathrm{cm}$ or larger).

in northeastern Italy (Giaiotti et al. 2003) and in MayJune in Greece (Kotinis-Zambakas 1989).

\section{c. Diurnal distribution}

Of the 240 cases, 45 (19\%) did not have sufficient information to determine their time of report to within a 120-min bin. Therefore, for the purposes of this section, only the 195 cases where the time was known to within 120 min will be discussed. These 195 cases were placed into 2 -h bins in local time (LT $=$ UTC $+3 \mathrm{~h}$ during summer in Finland).

Severe hail was most frequently observed during the afternoon (1400-1800 LT) and early evening (18002000 LT; Fig. 5), with around $74 \%$ of the cases occurring between 1400 and 2000 LT. At night, large-hail cases were rare (less than $3 \%$ of the cases), partly due to the unfavorable time in the diurnal cycle of convective storms (e.g., Punkka and Bister 2005) and partly due to fewer potential observers.

Interestingly, large hail tended to occur earlier (14001800 LT) than very large hail (1600-2000 LT). We speculate that this shift may be related to delayed initiation of convection due to a capping inversion in the most severe cases. The largest hail is mostly produced by supercell thunderstorms that favor slightly capped environments (e.g., Johns and Doswell 1992). We speculate that, if the environment were otherwise favorable for supercells, the absence of any convective inhibition would lead to early and widespread convective initiation, diminishing the likelihood of isolated supercells with intense updrafts to aid in the production of severe hail. The afternoon and early evening reports of hail are typical all around the world (e.g., Paul 1980; Dessens 


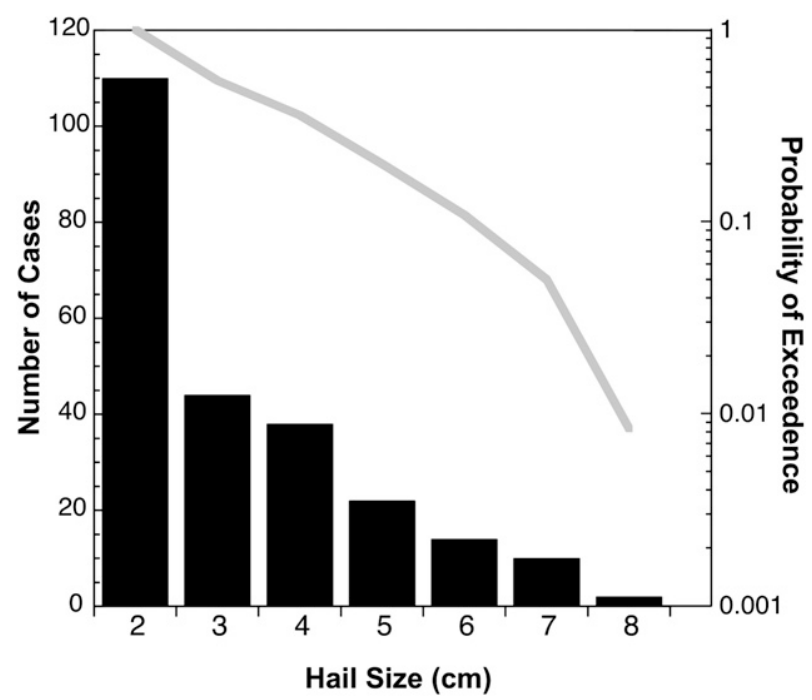

FIG. 6. The maximum hail-size distribution in Finland (black bars) and the probability of exceedence (gray line) during 19302006. Categories are labeled by the minimum hail size (e.g., the bar labeled " 2 " contains maximum hail sizes $2.0-2.9 \mathrm{~cm}$ ).

1986; Webb et al. 2001; Fraile et al. 2003; Schaefer et al. 2004; Schuster et al. 2005; Zhang et al. 2008). There have also been well-defined nighttime maxima in hail cases in some areas of the United States and China (Schaefer et al. 2004; Zhang et al. 2008).

\section{d. Size distribution}

Larger hailstones are less common than smaller hailstones (e.g., Changnon 1977), as are large raindrops compared to smaller ones (e.g., Federer and Waldvogel 1975; Cheng and English 1983). In Finland (Fig. 6), the maximum hail diameter (45\% of all 240 severe-hail cases) is in the smallest size collected for this study: $2.0-2.9 \mathrm{~cm}$ in diameter. Still, hail size smaller than $2 \mathrm{~cm}$ is expected to be the most common one, as storm-spotter hail report data from 2004-06 suggests: of 144 spotter reports of hail, 35 (24\%) are severe hail. Very large hail is reported more infrequently, although this size category does most of the property damage. Very large hail was observed in 87 cases $(36 \%)$ out of 240 cases in our dataset, but only $6 \%$ were at least $7 \mathrm{~cm}$ in diameter (Fig. 6). About $8 \%$ of the U.S. hail reports were $5.1 \mathrm{~cm}$ or 2.0 in. (Schaefer et al. 2004), compared to Kelly et al. (1985) $18 \%$ from the earlier U.S. dataset of 1955-83. The largest known hailstone in our dataset was $8 \mathrm{~cm}$ in diameter and has occurred twice. On 21 August 1968, hundreds of building and greenhouse windows were broken near the city of Lappeenranta in southeastern Finland, and, on 9 July 1972, cars were damaged and windows were broken in the center of the city of Tam- pere in central Finland. By comparison, the largest recorded hailstone in the world fell in Aurora, Nebraska, on 22 June 2003, measuring $17.5 \mathrm{~cm}$ in diameter (Knight and Knight 2005).

Because of the Finnish storm spotters and a greater awareness of severe weather among the general public, even marginally severe-hail cases (almost $2 \mathrm{~cm}$ ) have been better documented in recent years, similar to that seen in the United States (Schaefer et al. 2004). Information on the size distributions of hail is not presented in many studies from other locations. The distribution of severe hail in the United States during 1955-2002 (Schaefer et al. 2004) showed that $34 \%$ of reports were of the smallest size (penny size), but the shape of the distribution was not a smooth curve because of the typical practice in the United States for people to report the size of hail by comparison to golf balls or baseballs instead of quantitative measurements. In fact, golf-ball-sized hail (around $4 \mathrm{~cm}$ in diameter) was the second most common severe-hail size in the United States. Fortunately, without such a history of reporting practice, such problems do not seem to plague the Finnish hail dataset (Fig. 6).

Eleven years of hail-pad data from northeastern Italy (Friuli-Venezia Giulia, 1988-98) showed that approximately $6 \%$ of all hailstones were large hail, whereas the largest observed hailstones have been 6-7 cm in diameter (Giaiotti et al. 2001). In the Po River Valley in north-central Italy, the largest hailstones were at least $10 \mathrm{~cm}$ in diameter (Morgan 1973). The size distribution of maximum hailstone diameters in France showed that approximately $50 \%$ of 5100 cases were smaller than $2 \mathrm{~cm}$, the largest being $8 \mathrm{~cm}$ in diameter (Dessens 1986). The same dataset also showed that the frequency of $4 \mathrm{~cm}$ or larger hailstones varied between $5 \%$ and $20 \%$, depending on the location. Finally, in central Canada, the frequency of hailfalls with maximum hailstones larger than $3 \mathrm{~cm}$ was $6 \%$ of all cases, whereas the largest hailstones were 8-11.5 cm in diameter (Paul 1980).

\section{e. Geographical distribution}

Most severe-hail cases occurred in southern and western Finland, generally decreasing to the north (Fig. 7). Because the convective weather season is somewhat shorter in the north compared to southern and central Finland partly explains why fewer cases are observed in the north (as well as the lower population density). Many regions in Finland appear to be sparsely covered with hail reports. For example, most of the population in Finland lives in southern Finland (approximately 1.5 million people live in the Helsinki metropolitan area, out of the 5.3 million Finnish residents). Most of the observations are from near the larger cities and towns, which is common in other such datasets (e.g., Changnon 


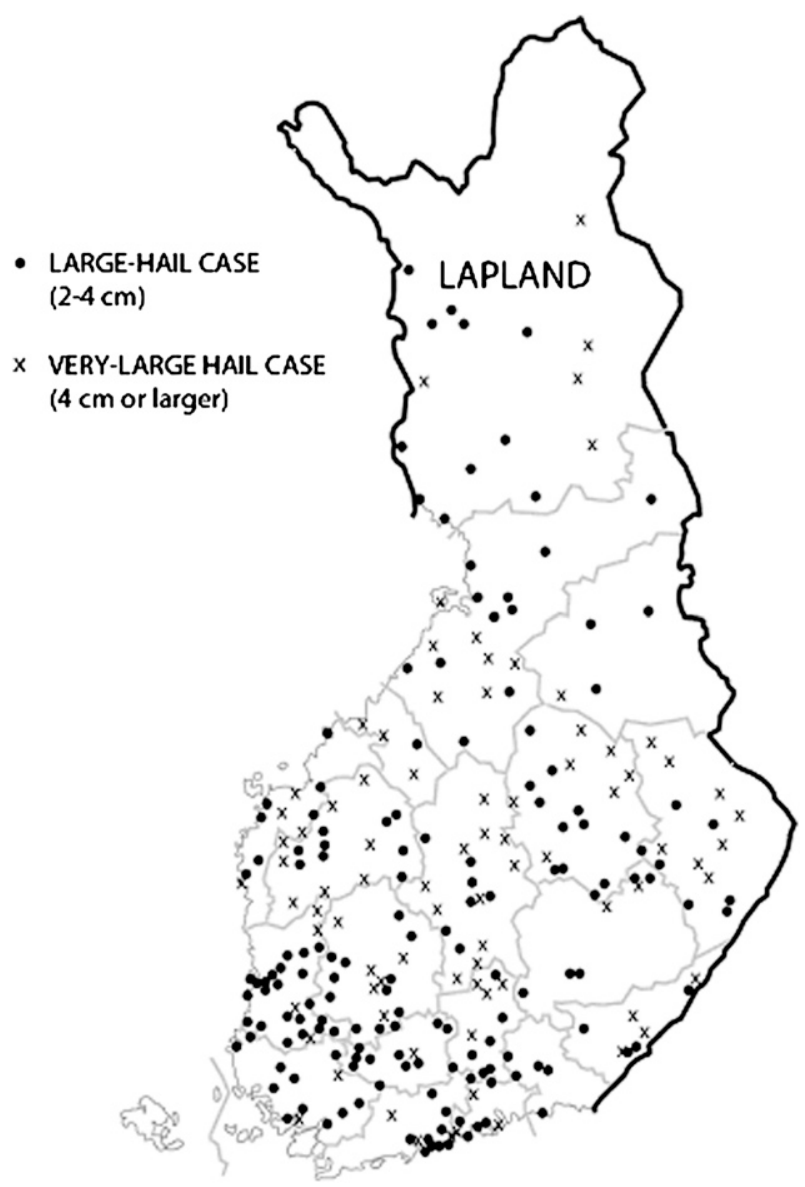

FIG. 7. Geographical distribution of severe-hail cases in Finland during 1930-2006. Black dots indicate cases of large hail $(2-3.9 \mathrm{~cm}$ in diameter) and $\mathrm{X}$ marks indicate the cases of very-large hail sizes (4 $\mathrm{cm}$ or larger).

1968). During the last $40 \mathrm{yr}$ in Finland, about 350000 people have moved out from the countryside into cities. Such a large number of people moving away from rural areas has likely affected the hail-detection frequency in these areas. Large lakes cover about $30 \%$ of the land surface in southeast Finland, apparently limiting the number of cases. Western Finland is an agriculturally intensive area with large coverage of crop fields, possibly explaining the large number of reports there. Specifically, reports of hail smaller than $4 \mathrm{~cm}$ (dots in Fig. 7) are more common than very large hail (X marks in Fig. 7) in western Finland. In this location, the distribution of reported hail sizes is probably closest to that in reality. Farther inland, over central and eastern Finland, these two size categories are almost equal. An alternative explanation might be that convective storms that develop along the western coastline and move eastward take time to develop hail at larger sizes, although this hypothesis has not been tested.

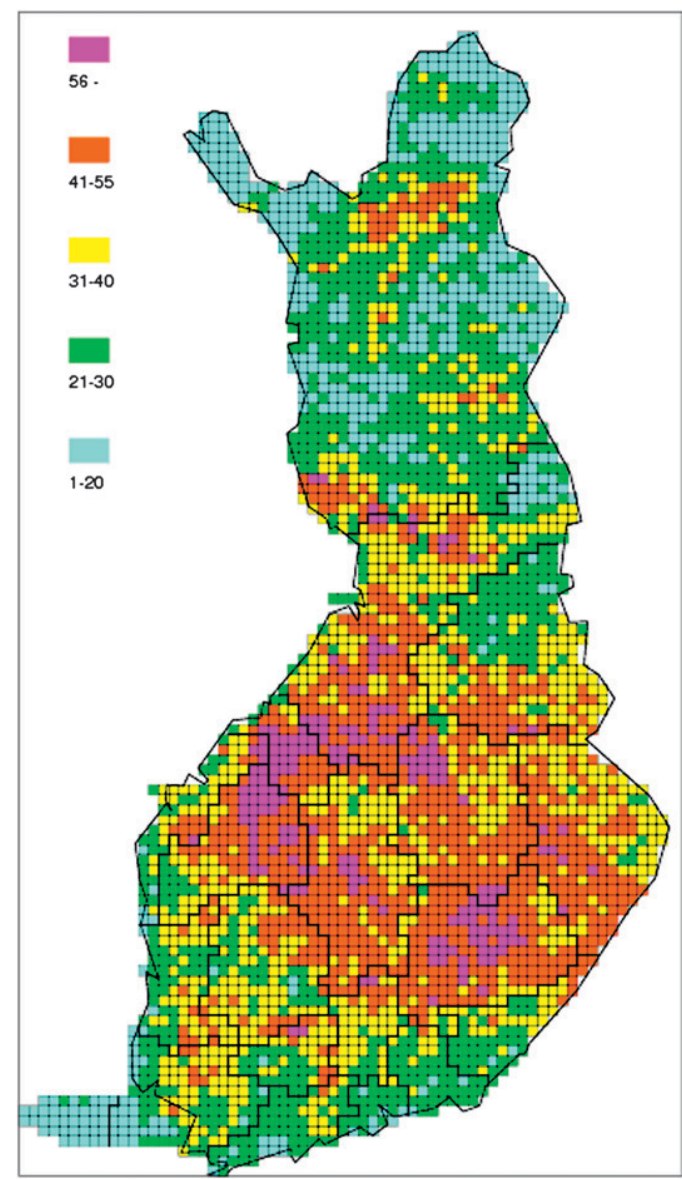

FIG. 8. The average ground flash density (number of flashes) on 10 $\mathrm{km} \times 10 \mathrm{~km}$ squares in Finland during 1998-2007.

Comparing the severe-hail case map (Fig. 7) to the cloud-to-ground lightning flash density map (Fig. 8) indicates the general northward decrease of both hail and lightning. Lightning occurrence, however, is maximized mainly in central Finland with relatively less occurrence along the south and west coasts (Fig. 8) where the hail cases are maximized (Fig. 7). Three issues are relevant when comparing the hail and lightning occurrence (cf. Figs. 7 and 8). First, the severe-hail dataset includes $77 \mathrm{yr}$ of reports but the lightning data is only from the last $10 \mathrm{yr}$ (1998-2007). Specifically, a single year may have too much weight in the lightning dataset, as was the case in 2003 when a majority of cloudto-ground lightning flashes occurred in west-central Finland (not shown), skewing the climatology. Similarly, most of the hail cases from western and southwestern Finland (minimum density in Fig. 8) occurred between the 1960s and 1980s. Second, cloud-to-ground lightning measurements over parts of Finland extend back to the 1960s, but the lightning detection network was 
modernized with more efficient and accurate detectors to cover the entire country in 1997. Third, excessive lightning can occur without hail and hail can occur without excessive lightning, so an exact correspondence between hail and lightning should not be expected as a rough measure of convective storm occurrence.

The northernmost severe-hail case in our dataset was made near $68.5^{\circ} \mathrm{N}$ on 5 July 2004. According to an eyewitness report, golf-ball-sized hailstones (around $4 \mathrm{~cm}$ ) dented a car. Given that only a hundred cars pass this rural road of northern Lapland each day, the driver of this car was quite unlucky (although lucky from the present study's point of view)! Have other countries reported any severe-hail cases that far north? The National Inquiry Response Team of Meteorological Service of Canada stated that the northernmost severe-hail cases in Canada probably occur south of $60^{\circ} \mathrm{N}$, and that severe hail likely does not reach as far north as $68.5^{\circ} \mathrm{N}$, in accordance with Etkin and Brun (1999). According to the Storm Data Web site, the northernmost severe-hail case in the United States (1955-2006) was recorded near $63^{\circ} \mathrm{N}$ on 28 June 2004 near Talkeetna, Susitna Valley, Alaska (see online at http://www4.ncdc.noaa.gov/cgi-win/ wwcgi.dll?wwEvent $\sim$ Storms). In Sweden, the northernmost severe-hail case took place just south of $68^{\circ} \mathrm{N}$ in Lainio on 23 June 1979. Thus, as far as we know, the Finnish case from $68.5^{\circ} \mathrm{N}$ is the northernmost documented severe-hail case in the world.

\section{Conclusions}

This article presents a climatology of severe hail (over $2 \mathrm{~cm}$ in diameter) in Finland during the 77-yr period 1930-2006. Cases were collected from newspapers, eyewitness reports, and, in recent years, from storm-spotter reports. Altogether, 240 severe-hail cases were found all around the country. According to the most recent $10 \mathrm{yr}$, an annual average of about 10 severe-hail cases occur during 5 severe-hail days. The number of cases has risen considerably in recent years, mostly due to the increase of marginally severe-hail reports, the storm-spotter network, the growing interest in severe weather among the general public and media, and rapid means of communication (e.g., mobile phones, computers, digital cameras). The same kind of trend has been seen in the hail data from the United States (Schaefer et al. 2004) and southeastern Australia (Schuster et al. 2005). This project also spurred FMI to collect reports in real-time via a hail-reporting form, with the goal of increasing the hail dataset in the future.

Large hail in Finland can occur anytime between May and mid-September, with the peak time for severe hail being late June to early August when over $85 \%$ of cases have occurred. July was the most active month for severe hail (66\% of cases). Cloud-to-ground lightning flashes in Finland (Tuomi and Mäkelä 2003) have a similar annual distribution compared to severe hail. Afternoon and early evening hours (1400-2000 LT) are the peak times of severe-hail cases. Very large hail (4 cm or larger) occurs mostly in July (69\%) and mainly in the early evening hours (1600-2000 LT), a little later than the peak time for large hail $(2-4 \mathrm{~cm})$ at 1400-1800 LT. The reason for this time difference is not fully known.

The maximum diameters of hailstones are typically smaller than $3 \mathrm{~cm}$ ( $45 \%$ of the severe-hail cases), although giant hailstones of at least $5 \mathrm{~cm}$ are less common $(19 \%)$. The storm spotters' reports of all hail sizes (2004-2006) indicate that the maximum hailstone size in Finland usually falls short of the 2-cm threshold for this study, but even tennis-ball- and baseball-size hail (6.4-7.0 $\mathrm{cm}$ or $2.5-2.75 \mathrm{in}$.) have been reported a few times.

Because Finland is mostly forested with many large lakes and a relatively low population density, underreporting of severe hail is significant. The majority of severe-hail reports are from the agricultural areas in western Finland. A large number of reports are also near cities and towns. Most severe-hail cases occurred in southern and western Finland, generally decreasing to the north, with the majority of the cases near population centers. The proportion of large hail to all severe-hail cases is greatest over the agricultural area in southwestern Finland where any crop damage caused by severe hail is more likely to be reported. In this location, the distribution of reported hail sizes is probably closest to that in reality. In northern Finland, severe hail is observed infrequently, mostly due to the low population density and shorter convective storm season. Nevertheless, the northernmost large-hail case took place near $68.5^{\circ} \mathrm{N}$ latitude, possibly making it the northernmost observed case of severe hail in the world.

Acknowledgments. We thank Weine Josefsson (Swedish Meteorological and Hydrological Institute), Knut Iden (Norwegian Meteorological Institute), John Cappelen (Danish Meteorological Institute), Ene Tillmann (Estonian Meteorological and Hydrological Institute), and Sylvain Boutot (Environment Canada) for providing information about their country's hail reports. We also thank Antti Mäkelä (FMI) for providing Figs. 4 and 8, and we thank Harold Brooks and two anonymous reviewers for their comments that helped improve the manuscript. Partial funding for Schultz comes from Vaisala Oyj. Special thanks to all the Finnish storm spotters who made some of the datasets possible. 


\section{REFERENCES}

Basara, J. B., D. C. Cheresnick, D. Mitchell, and B. G. Illston, 2007: An analysis of severe hail swaths in the southern Plains of the United States. Trans. GIS, 11 (4), 531-554.

Battan, L. J., 1977: Weather modification in the Soviet Union. Bull. Amer. Meteor. Soc., 58, 4-19.

Changnon, S. A., Jr., 1968: Effect of sampling density on areal extent of damaging hail. J. Appl. Meteor., 7, 518-521. , 1977: The scales of hail. J. Appl. Meteor., 16, 626-648.

Changnon, S. A., 1999: Data and approaches for determining hail risk in the contiguous United States. J. Appl. Meteor., 38, 1730-1739.

- , and D. Changnon, 2000: Long-term fluctuations in hail incidences in the United States. J. Climate, 13, 658-664.

Cheng, L., and M. English, 1983: A relationship between hailstone concentration and size. J. Atmos. Sci., 40, 204-213.

Dessens, J., 1986: Hail in southwestern France. I: Hailfall characteristics and hailstorm environment. J. Climate Appl. Meteor., 25, 35-47.

Doswell, C. A., III, 2001: Severe convective storms-An overview. Severe Convective Storms, Meteor. Monogr., No. 50, Amer. Meteor. Soc., 1-26.

- 2003: Societal impacts of severe thunderstorms and tornadoes: Lessons learned and implications for Europe. Atmos. Res., 67-68, 135-152.

_- 2007: Small sample size and data quality issues illustrated using tornado occurrence data. Electron. J. Severe Storms Meteor., 2 (5), 1-16.

— H. E. Brooks, and M. P. Kay, 2005: Climatological estimates of daily local nontornadic severe thunderstorm probability for the United States. Wea. Forecasting, 20, 577-595.

Etkin, D., and S. E. Brun, 1999: A note on Canada's hail climatology: 1977-1993. Int. J. Climatol., 19, 1357-1373.

Federer, B., and A. Waldvogel, 1975: Hail and raindrop size distributions from a Swiss multicell storm. J. Appl. Meteor., 14, 91-97.

—, and Coauthors, 1986: Main results of Grossversuch IV. J. Climate Appl. Meteor., 25, 917-957.

Fraile, R., A. Castro, J. L. Sánchez, J. L. Marcos, and L. López, 2001: Noteworthy C-band radar parameters of storms on hail days in northwestern Spain. Atmos. Res., 59-60, 41-61.

— C. Berthet, J. Dessens, and J. L. Sánchez, 2003: Return periods of severe hailfalls computed from hailpad data. Atmos. Res., 67-68, 189-202.

Frisby, E. M., and H. W. Sansom, 1967: Hail incidence in the Tropics. J. Appl. Meteor., 6, 339-354.

Galway, J. G., 1989: The evolution of severe thunderstorm criteria within the Weather Service. Wea. Forecasting, 4, 585-592.

Giaiotti, D., E. Gianesini, and F. Stel, 2001: Heuristic considerations pertaining to hailstone size distribution on the plain of Friuli-Venezia Giulia. Atmos. Res., 57, 269-288.

_- S. Nordio, and F. Stel, 2003: The climatology of hail in the plain of Friuli- Venezia Giulia. Atmos. Res., 67-68, 247-259.

Hales, J. E., Jr., 1988: Improving the watch/warning program through use of significant event data. Preprints, 15th Conf. on Severe Local Storms, Baltimore, MD, Amer. Meteor. Soc., $165-168$.

Houze, R. A., Jr., W. Schmid, R. G. Fovell, and H.-H. Schiesser, 1993: Hailstorms in Switzerland: Left movers, right movers, and false hooks. Mon. Wea. Rev., 121, 3345-3370.
Järvi, L., and Coauthors, 2007: Micrometeorological observation of a microburst in southern Finland. Bound.-Layer Meteor., 125, 343-359.

Johns, R. H., and W. D. Hirt, 1987: Derechos: Widespread convectively induced windstorms. Wea. Forecasting, 2, 32-49.

_ Wea. Forecasting, 7, 588-612.

Kelly, D. L., J. T. Schaefer, and C. A. Doswell III, 1985: Climatology of nontornadic severe thunderstorm events in the United States. Mon. Wea. Rev., 113, 1997-2014.

Knight, C. A., and N. C. Knight, 2005: Very large hailstones from Aurora, Nebraska. Bull. Amer. Meteor. Soc., 86, 17731781.

Kotinis-Zambakas, S. R., 1989: Average spatial patterns of hail days in Greece. J. Climate, 2, 508-511.

Lemons, H., 1942: Hail as a factor in the regional climatology of the United States. Geogr. Rev., 32, 471-475.

López, L., J. L. Marcos, J. L. Sánchez, A. Castro, and R. Fraile, 2001: CAPE values and hailstorms on northwestern Spain. Atmos. Res., 56, 147-160.

Ludlam, F. H., 1980: Clouds and Storms. The Pennsylvania State University Press, 405 pp.

Morgan, G. M., Jr., 1973: A general description of the hail problem in the Po Valley of northern Italy. J. Appl. Meteor., 12, 338-353.

Outinen, K., and J. Teittinen, 2007: Case study of a tornadic supercell in Finland 28th August 2005. Preprints, Fourth European Conf. on Severe Storms, Trieste, Italy, ARPA, 5.14. [Available online at http://www.essl.org/ECSS/2007/preprints/ chapter_05.pdf.]

Paul, A. H., 1980: Hailstorms in southern Saskatchewan. J. Appl. Meteor., 19, 305-313.

Punkka, A.-J., and M. Bister, 2005: Occurrence of summertime convective precipitation and mesoscale convective systems in Finland during 2000-01. Mon. Wea. Rev., 133, 362-373.

_ analysis of a high-latitude derecho-severe thunderstorm outbreak in Finland on 5 July 2002. Wea. Forecasting, 21, $752-763$.

Ramis, C., J. Arús, M. López, and A. M. Mestres, 1997: Two cases of severe weather in Catalonia (Spain): An observational study. Meteor. Appl., 4, 207-217.

Rauhala, J., and D. M. Schultz, 2008: Severe thunderstorm and tornado warnings in Europe. Atmos. Res., in press.

Saltikoff, E., J. Tuovinen, T. Kuitunen, H. Hohti, and J. Kotro, 2008: Hail in Finland seen with weather radar and in newspapers. Proc. Fifth European Conf. on Radar in Meteorology and Hydrology, Helsinki, Finland, Finnish Meteorological Institute, 12.3. [Available online at http://erad2008.fmi.fi/ proceedings/extended/erad2008-0030-extended.pdf.]

Sánchez, J. L., R. Fraile, J. L. de la Madrid, M. T. de la Fuente, P. Rodríguez, and A. Castro, 1996: Crop damage: The hail size factor. J. Appl. Meteor., 35, 1535-1541.

Schaefer, J. T., J. J. Levit, S. J. Weiss, and D. W. McCarthy, 2004: The frequency of large hail over the contiguous United States. Preprints, 14th Conf. on Applied Climatology, Seattle, WA, Amer. Meteor. Soc., 3.3. [Available online at http://ams. confex.com/ams/84Annual/techprogram/paper_69834.htm.]

Schmid, W., and A. Waldvogel, 1986: Radar hail profiles in Switzerland. J. Climate Appl. Meteor., 25, 1002-1011.

Schuster, S. S., R. J. Blong, and M. S. Speer, 2005: A hail climatology of the greater Sydney area and New South Wales, Australia. Int. J. Climatol., 25, 1633-1650. 
Simeonov, P., 1996: An overview of crop hail damage and evaluation of hail suppression efficiency in Bulgaria. J. Appl. Meteor., 35, 1574-1581.

Teittinen, J., and A.-J. Punkka, 2004: Severe thunderstorm radar signatures of 5 July 2002 derecho in Finland. Preprints, 22nd Conf. on Severe Local Storms, Hyannis, MA, Amer. Meteor. Soc., 7A.4. [Available online at http://ams.confex.com/ams/ 11aram22sls/techprogram/paper_82041.htm.]

_ , and H. E. Brooks, 2006: A climatology of tornadoes in Finland. Preprints, 23rd Conf. on Severe Local Storms, St. Louis, MO, Amer. Meteor. Soc., 9.3. [Available online at http:// ams.confex.com/ams/23SLS/techprogram/paper_115319.htm.] , J. G. LaDue, H. Hohti, and R. A. Brown, 2006: Analysis of a tornadic mini-supercell in Finland by using Doppler radar. Preprints, 23rd Conf. on Severe Local Storms, St. Louis, MO,
Amer. Meteor. Soc., P6.1. [Available online at http://ams. confex.com/ams/23SLS/techprogram/paper_115430.htm.]

Tuomi, T. J., and A. Mäkelä, 2003: Synoptic classification of thunderstorms in Finland. Geophysical, 39, 3-30.

Tuovinen, J.-P., 2007: Suurien rakeiden klimatologia Suomessa 1930-2006 (The severe hail climatology in Finland 1930-2006). M.S. thesis, Department of Physics, University of Helsinki, 86 pp. Vinet, F., 2001: Climatology of hail in France. Atmos. Res., 56, 309-323.

Waldvogel, A., B. Federer, and P. Grimm, 1979: Criteria for the detection of hail cells. J. Appl. Meteor., 18, 1521-1525.

Webb, J., D. M. Elsom, and D. J. Reynolds, 2001: Climatology of severe hailstorms in Great Britain. Atmos. Res., 56, 291-308.

Zhang, C., Q. Zhang, and Y. Wang, 2008: Climatology of hail in China: 1961-2005. J. Appl. Meteor. Climatol., 47, 795-804. 